\title{
Merlin and Stonehenge in Daina Chaviano’s Fables of an Extraterrestrial Grandmother
}

\author{
Robin McAllister \\ Sacred Heart University, Fairfield, Ct., USA
}

\begin{abstract}
When Merlin first appears in Chaviano's Fables of an Extraterrestrial Grandmother as the wizard Soio, he reflects the imagination of Ana, the adolescent protagonist of the science fiction novel as she is in the process of writing the very novel the reader is reading. Later she will discover that her fictional creations are not the invention of her imagination but exist autonomously in parallel universes and are using her as a vehicle of inter-dimensional travel through time and space. Soio/Merlin gazes into his crystal ball, a microcosm that gathers the space-time energy fields of the parallel universes, and sees visions of the protagonists whose modes of existence are real in one and fictional in another parallel universe. Merlin is a Druid in exile from the Neolithic world of Celtic Britain who has crossed over from earthly life to existence in Rybel, a parallel universe. He had crossed over by lining up the Stone of the Past and the Mirror of the Future at the great circle of Stonehenge. The stone circle functioned as an astronomical observatory. Stonehenge is a microcosm, a circle that reflects and coordinates the larger circle of the universe, symbolized and embodied in the sphere or crystal ball that Merlin transmits to Ana in the form of the novel being read. All the characters are trying to coordinate dimensions of space and time in order to fly from one parallel universe to another. Chaviano emphasizes crossing boundaries of time and space. Her characters live in one world but belonging to another, yearn to make contact with the forces of the universe that will bring them home. Chaviano's use of the Merlin legend is original and takes into account archaeological evidence about the Celts, Druids, and Stonehenge.
\end{abstract}

Keywords: Daina Chaviano, science fiction, Merlin, Stonehenge

\section{Introduction}

When Merlin first appears in Cuban science fiction writer, Daina Chaviano's Fables of an Extraterrestrial Grandmother as the wizard Soio, he reflects the imagination of Ana, the adolescent protagonist of the novel. Ana is writing the very novel we are in the process of reading. Only later she will discover that her fictional creations are not the invention of her imagination but exist autonomously in parallel universes and are using her as a vehicle of inter-dimensional travel through time and space.

\section{Merlin in Exile in Parallel Dimensions of Time and Space}

Merlin first appears to us as Soio, the archetypal wizard with his crystal ball:

Soio opened his eyes, and still half-asleep, believed he was dreaming. The images that had awakened him continued floating in his mind, though already they were starting to fade away. A simple dream? Or a pre-vision?

Robin McAllister, Ph.D., Associate Professor, Department of English, Sacred Heart University. 
He remained a few moments without moving on the cold cot. A soft clarity was insinuating itself in the horizon that he could look out on from his room situated on the summit of a mountain. He got up slowly and the nails creaked sorrowfully. Then he walked to disperse the remnants of the dream, but visions kept flitting within his mind.

He turned his face toward the wide bay window that opened to the wind of the east. The stars shown with almost unnatural splendor: their light was clear and deep. He believed he could feel how their rays arrived from remote places and penetrated to the depths of his bones. Acting on impulse he stuck his body half out of the orifice open in the rock. It was the very best experience in the world to waken when the night was dying and breathe the morning air under the purest shining of the stars. In moments like this he was happy. He remained in that position several minutes because, despite the dampness, it was good for his old senses to perceive the energy coming to him from the universe. Afterwards he abandoned the window to find a seat by the coals of the fire. It was so dark he let himself be guided by the red pupils that winked at him from the corner. While he watched the logs in the fire, he felt anew a pressing disquietude.

He looked for a candle that rested on a disordered shelf and lit it. After setting it close, he sat down in front of a table where there was a ball covered with a cloth. Upon uncovering it, he observed weak reflections over its polished surface.

The ancient one caressed the sphere, and something moved in its interior, but he did not let himself be deceived. He knew well that which he had before him: its smooth, opaque sides, whose coldness would start yielding through the constant warmth of his hands; and the first shadows that would not be shadows, but the simple reflection of the candle...until the nexus between his mind and the object was established. With his gaze fixed in the sphere, he rubbed again and again, again and again...The frozen surface accumulated the heat emanating from his body; the opaque shell acted like a magnet that attracted and distributed forces; the object transformed itself into a warm fruit that absorbed the energy of the living person who touched it. Little by little it illuminated itself as if a hidden fountain had begun to operate in its interior.

Outside the darkness persisted over the landscape that surrounded the mountain: the enormous valley circled by woods and, in the distance, other valleys and other woods.

The glow of the sphere augmented and diminished at various times. Certain silhouettes undulated in its depths; various hisses, murmurs, chirps let themselves be heard from various parts of the room. And finally the luminosity established itself, converting the sphere into a lamp that radiated light over the face of the man. The shadows were displaced. Soio followed with his gaze the movement of monstrous figures with indefinable contours. Almost imperceptibly the silhouettes were replaced by the face of a girl.

The old man's hands rubbed more anxiously, there was more energy, and the image cleared up. She appeared pale and tired. Enormous eyes. Long, dark hair. She seemed beautiful, but her exhausted appearance prevented verifying it. The colors of the image were tenuous although precise. Soio observed the dense underbrush of wild, green vines that made her steps difficult; the abundance of rocks on the ground; the blue dress with striped hem which caught on anything sticking over the trail. She stopped for a moment, examined the terrain, and then continued her way. A moment later she repeated the operation. Soio realized that she felt spied upon, and without knowing why, he closed his eyes. When he opened them anew, the girl had disappeared and the vision of the woods disappeared like mist.

He tried to reestablish the flow of energy by rubbing with force, but the connection had broken at some point. Nevertheless he continued to caress the crystal. His hands came and went as if they wanted to make that improvised mirror shine; finally some shadows transformed themselves into silhouettes, and those into defined figures.

The ancient one contemplated the room sketched out in the very heart of the sphere: the narrow bed, the pictures on the wall, and a table full of papers and books over which someone bent. A woman? No, scarcely a girl. He was able to verify it when she turned toward him with a thoughtful expression...The room and its furnishings were all strange to him, but not she: she was the same young girl that he had just seen a few minutes before trying to cross the undergrowth of vines. He studied her attentively. Every sign of fatigue or fear had disappeared from her face, and she was dressed differently: instead of the vaporous dress, from her waist to her ankles she had on something that tightly circled both her legs, and from the waist to her neck she wore a blouse with wide sleeves. 
When she bent over the papers, Soio called up the memory of the previous wanderer in the woods comparing that image with this one. The girl parted the hair that fell over her shoulders, and the ancient one shivered. She was the same woman. And she was not.

For some moments his thoughts went off to some remote place. When he returned to himself, the image had disappeared from the sphere that now turned into a cold, dark ball, insensible to the heat of the hands that tried to revive it. He knew every effort would be futile since he had exhausted the energy of that day in visions.

He got up and covered the object up again with the cloth. Then he looked in the direction of the eastern window. Agoy slowly rose up on the horizon.

Soio remained for a certain time sunk in profound thoughts, and then he knew without room for doubt, that the beginning had arrived. It would be fair to say he had no fear even though in that beginning he could encounter his end, and he knew it. (Chaviano, 1988, pp. 29-31)

Soio/Merlin gazing into the crystal ball, a microcosm that gathers the space-time energy fields of the universe, is able to see into parallel universes and evokes visions of the protagonists in those universes whose modes of existence are real in one and fictional in another. Arlena and Ana are the same person in two distinct universes, parallel worlds. Whoever has the sphere can travel in time and space.

Merlin is a Druid in exile from the Neolithic world of Celtic Britain in the parallel universe of Faidir, awaiting the messengers who will help him coordinate the Stone of the Past and the Mirror of the Future to open up the trans-dimensional frontiers of the universe so that he can return to earth. The last time Merlin had lined up the Stone and Mirror at the Great Circle of Stonehenge, he had suddenly crossed over from earthly life to existence on Rybel, a parallel universe.

Soio/Merlin remembers the moment in which he crossed over from earth to the parallel universe of Rybel:

He drew near to the window and began again to recall all that he had lived: from the terrible feeling of dizziness that had struck him the first time in childhood, when he had tried to cross a river, to the occasion when he had looked down on himself, as if he had abandoned his own body. Again he heard the stories of those beings called magi, magicians, who had visions of past and future events, unable to travel over flowing water, obliged to remain virgins, unless they wanted to lose their powers...then he knew why the visions struck him, he understood the cause of the stupor that paralyzed him, and of the strange awakening surrounded by people who asked for more details of the prediction he had just formulated-a prediction he never succeeded in remembering, to the astonishment and distrust of those who had listened to it moments before...For some reason he was different, apart, from the men of his village. Any yet, on the surface nothing differentiated him from the rest: he ate, slept, dreamed, believed in the pleasure of laughter, and loved his country with profound nostalgia, that place, almost forgotten, that still existed in another dimension of space.

He had been born a magus. And his first name had been that of the falcon, Merlin. For years he lived in the cave he had inherited from his master, a spacious, comfortable grotto that guarded a mirror and stone, the Mirror and the Stone in which you could read time. Where had his master gotten them? Soio/Merlin did not know. The ancient one had told him a story about lightening, wind, and a creature with wings who opened a path in the invisible turbulence of the air in order to leave him those objects. Struck by the terror, blinded by the splendor, the master kept both objects in a nearby cave, which he visited frequently, until they began to reveal their hidden powers.

His master was a wise man, but the wisdom of the objects given to him by the gods of another universe was greater because it was born from a knowledge more ancient than man. And that power contained in the Stone and Mirror instructed his capacities better than any cult mystery in which he participated.

Much later Merlin arrived, a nubile pup hiding a visionary spirit. The ancient one adopted him as a disciple and taught him the secrets of the grotto. When he died, Merlin occupied his dwelling. For years and years. Kings and kingdoms followed one another with which Merlin maintained a close and influential relationship... 
Soio stepped back from the window. For a moment he wanted to forget all his former life that struck him now as the life of someone else, since even his name was different. The forces that governed the objects had also transformed his existence.

One afternoon of late autumn, when the plain of the estuary filled with a dry yellow straw that months before had been a brilliant green under the sun, Merlin felt the familiar sensation of nausea that preceded the arrival of the visions. He went into the cave to set up the Stone in a straight line with the Mirror and, in this way, attract the images that emerged incoherently from his mind. That was the last thing he did in his world. The terrible voice of a hurricane struck his beard, the sky seemed to open like a well of light, and more dizziness and nausea made him double over and fall on a different world. He was on Rybel, but would not know it for weeks. A new language and a foreign sky were insufficient to make him understand that that place was not his own. (Chaviano, 1988, pp. 72-73)

\section{Stonehenge}

Later we find the reason Merlin has crossed from one existence to another. Ana has resorted to the Ouija board to put herself in contact with subconscious images from her genetic memory. All images are real, Ana explains, because the universe with its worlds and its realities is infinite. A character of my imagination, she tells a friend, can also exist in real life. Merlin had adored the stones of the Great Circle, his name for Stonehenge. The stone circle functioned as an astronomical observatory. The dancing or revolution of the stones refers to their apparent motion in relation to the stars. The Great Circle wheeled and wheeled under the Celtic sky. A hole opened in time and space, and Merlin fell into it. Something in the arrangement of the stars caused him to disappear. The magician was lost. Only the stone circle remained.

Stonehenge is a microcosm, a circle that reflects and coordinates the larger circle of the universe, symbolized and embodied in the sphere or crystal ball that Merlin transmits to Ana in the form of the novel we are reading. Soio/Merlin later explains to Arlena:

In any case, what do I know, an ignorant druid initiated by my masters into the secrets of levitation next to the Great Circle? We also performed forbidden ceremonies there. The stones indicated punctually the arrival of the solstices and equinoxes, of eclipses and lunar phases, the position of some stars and the influence of cosmic energies. All that, joined to the force of the earth, which in that location has more power than elsewhere, provoked an amazing effect in certain marked moments in the calendar. If on an ordinary day we could elevate ourselves a finger length above the surface of the ground, in those favorable instants we succeeded in ascending twice the height of a man, and on even more propitious occasions we flew like birds...For that reason I am able to accept the enigma of the talismans. If normally they permit us to glimpse other worlds or half see the past and future, under better conditions they make possible the flight to other places. (Chaviano, 1988, pp. 274-275)

All the characters in Fables of an Extraterrestrial Grandmother are trying to coordinate dimensions of space and time in order to fly from one parallel universe to another across various dimensions of time. Merlin must coordinate Ana, our protagonist writer in the novel, sitting in Havana, with Arlena, Ana's "fictional" protagonist fleeing through the jungle of Rybel toward the Valley of the Sylphs and Merlin's cave, with one moment in time, when the Stone of the Past can be aligned with the Mirror of the Future, and Merlin and Arlena can cross over the open frontiers of time and space to return to their own worlds again. In Arthurian legend Merlin disappears from earth after falling in love with the beautiful enchantress Vivien, who imprisons him in a floating castle or cave, where he sleeps away eternity, but his voice is heard from time to time. Chaviano, however, returns Merlin to a pre-Celtic, Neolithic time of the original builders of Stonehenge, and we hear no more about his fate. 
Chaviano's emphasis on crossing boundaries of time and space from one parallel universe to another and on characters living in one world but belonging to another, yearning to make contact with the forces of the universe that will bring them home suggests the theme of in shamanism (McAllister, 2014). The shaman leaves the world behind in shamanic trance and makes a spirit flight to the world of the dead where he or she encounters an ancestor who tells the shaman the myths that reveal the true nature of reality. The shaman returns to the world of the living with healing and teaching powers. Both Ana and Soio resemble shamans. The act of writing for Ana is an act of mental regression to pre-rational, subconscious shamanic trance states. Soio/Merlin resembles the ancestor spirit who reveals, and in this case enables, the true forces of the universe (symbolized by the crystal ball) to work their liberating powers.

\section{Conclusion}

Soio/Merlin represents the ancestor figure, an all-knowing, all-powerful magus or magician, whom Ana encounters in dream visions. Merlin will coordinate the flights across space and time that will conclude with his return to earth and Ana's completion of the novel we are in the process of reading. Chaviano's use of the Merlin legend is original and takes into account archaeological evidence about the Celts, Druids, and Stonehenge. The idea of trans-dimensional flight and parallel universes might be said to have its origins in Celtic mythology. In Celtic religion the Druid priest is a shaman and shift-changer, someone who can cross over the boundaries of the parallel worlds of the ancestors and the living, someone who can change into a bird and fly from one realm to the other and back. The most conspicuous element of the Merlin legend Chaviano omits from her creation of Soio/Merlin is the legend of Vivien/Nimue/Niniane and her enchantment and perpetual imprisonment of Merlin. Soio/Merlin denies he has ever heard of this girl when Ana brings up her name. He insists in an Epilogue that he returned to earth and Stonehenge, but in a Neolithic time prior to his own age with Arthur. Perhaps there is another reason. Ana is Vivien, but an Anti-Vivien who uses Soio/Merlin's magical powers not to entrap him but to liberate him across the frontiers of space and time in the magical sphere which is Fables of an Extraterrestrial Grandmother.

\section{References}

Burl, A. (1979). Rings of stone: The prehistoric stone circles of Britain and Ireland. New Haven: Ticknor and Fields.

Chaviano, D. (1988). Fabulas de una abuela extraterrestre (Fables of an extraterrestrial grandmother). La Habana, Cuba: Editorial Letras Cubanas.

Goodrich, N. L. (1988). Merlin. New York: Harper and Row.

McAllister, R. (2014). Shamanic imagination in Daina Chaviano's Fables of an Extraterrestrial Grandmother. Journal of Literature and Art Studies, 4, 817-821. 